\title{
Improved Immunohistochemical Detection of Type 1 Insulin-Like Growth Factor Receptor in Human Tumors
}

Tamara Aleksic ${ }^{1 *}$, Andrew Ross Worrall' ${ }^{1}$, Clare Verrill ${ }^{2}$, Helen Turley ${ }^{2}$, Leticia Campo ${ }^{1}$ and Valentine M Macaulay ${ }^{1,3}$

${ }^{1}$ Department of Oncology, Old Road Campus Research Building, Roosevelt Drive, Oxford OX3 7DQ, UK

${ }^{2}$ Department of Cellular Pathology, Oxford University Hospitals NHS Foundation Trust, John Radcliffe Hospital, Oxford OX3 9DU, UK

${ }^{3}$ Oxford Cancer and Haematology Centre, Oxford University Hospitals NHS Foundation Trust, Churchill Hospital, Oxford OX3 7LJ, UK

\begin{abstract}
Background: Insulin-like growth factors (IGFs) are known to play important roles in cancer biology, prompting evaluation of drugs targeting type 1 IGF receptor (IGF-1R). However, there is considerable lack of consensus in immunohistochemical (IHC) studies of IGF-1R in human tumors, confounding attempts to assess the predictive and prognostic significance of IGF-1R expression and subcellular localization. Likely sources of variation include use of different IGF-1R polyclonal antibodies and methods for IHC. Here, we aimed to develop a robust IGF-1R IHC protocol using a monoclonal antibody, suitable for use in formalin-fixed paraffin-embedded (FFPE) tissues.

Methods: Using controls including samples of FFPE tissues and tumor cells of defined IGF-1R expression, we used IHC and western blotting to compare polyclonal antibody \#3027 with monoclonals \#9750 and \#14534 (Cell Signaling Technology).

Results: Compared with \#3027, the monoclonals exhibited superior discrimination between IGF-1R-high and IGF-1R-deficient cells in manual IHC, signal generated by \#9750 reflecting differences in IGF-1R expression detected by western blotting. In tissues, IGF-1R detected by \#14534 was predominantly plasma membrane-associated, while \#9750 detected IGF-1R in the plasma membranes, cytoplasm and nucleus of prostate and renal cancers, recapitulating appearances we described using previous lots of \#3027, and reflecting subcellular localizations reported using other techniques. Use of \#9750 and \#14534 in an autostainer showed adequate differentiation of high vs low IGF-1R cells, but did not recapitulate appearances of manually-stained tissues. We provide a detailed protocol for the preferred manual method using $\# 9750$.
\end{abstract}

Conclusion: Standardization of IGF-1R IHC will promote understanding of the role of IGF-1R in tumor biology, and its potential as a candidate prognostic and predictive biomarker.

Keywords: Cancer; Insulin-like growth factor; Type 1 IGF receptor; IGF-1R; Nuclear IGF-1R; Immunohistochemistry; FFPE; Antigen retrieval

Abbreviations: IGF: Insulin-like growth factor; IGF-1R: Type 1 IGF receptor; IHC: Immunohistochemistry; FFPE: Formalin-fixed, paraffin-embedded; NSCLC: Non-small cell lung cancer

\section{Introduction}

The contribution of insulin-like growth factors (IGFs) to cancer biology has been extensively studied in cell lines, revealing that IGFs activate type 1 IGF receptors (IGF-1Rs) to promote cell cycle progression, cell survival, motility and invasion $[1,2]$. These findings provoked interest in studying IGF-1R expression in clinical cancers, and in development of drugs that block IGF signaling. However, there has been striking variation in reported IGF-1R expression in tumors and normal tissues when detected by immunohistochemistry (IHC). For example IGF-1R was reported to be unchanged or down -regulated in prostate cancer compared with benign prostate $[3,4]$, although since our report of IGF-1R up-regulation at the mRNA and protein level [5] most publications support up-regulation [6-8].

This lack of consensus also confounds attempts to interpret results of clinical trials of novel IGF inhibitory drugs. Early trials reported striking clinical responses to IGF-1R inhibition e.g., Ref. [9], but later trials showed very limited activity in unselected patients (reviewed in Ref. [10]. This raises the question as to whether tumor IGF-1R expression correlates with sensitivity to IGF-1R inhibition. Preclinical reports supporting such a link include studies in non-small cell lung cancer (NSCLC), breast and colorectal cancer, rhabdomyosarcoma,
Ewing family tumours and neuroblastoma [11-14]. However, other preclinical and some clinical studies found IGF-1R expression not to associate with response to IGF-1R inhibition in breast cancer, NSCLC and sarcomas [15-17]. While it is possible that IGF-1R is predictive of response in some tumor types but not others, it is also likely that technical differences in IHC protocols contribute to the apparent variation in significance of IGF-1R expression. Notably, the study conducted by Schwartz and colleagues found no difference in clinical activity of IGF-1R antibody cixutumumab with temsirolimus in patients whose tumors were IGF-1R 'positive' or 'negative' by IHC using the automated Ventana platform [17]. This trial also assessed tumor IGF-1R in a subset of patients by western blotting of fresh tumor lysates, resulting in detection of IGF-1R in all 'IGF-1R negative' tumors that were tested.

*Corresponding author: Dr. T. Aleksic, Department of Oncology, Old Road Campus Research Building, Roosevelt Drive, Oxford OX3 7DQ, UK, Tel: +44(0)1865617337; E-mail: tamara.aleksic@oncology.ox.ac.uk

Received January 12, 2016; Accepted January 21, 2016; Published January 25 2016

Citation: Aleksic T, Worrall AR, Verrill C, Turley H, Campo L, et al. (2016) Improved Immunohistochemical Detection of Type 1 Insulin-Like Growth Factor Receptor in Human Tumors. Immunochem Immunopathol 2: 114. doi: 10.4172/24699756.1000114

Copyright: (C) 2016 Aleksic T, et al. This is an open-access article distributed under the terms of the Creative Commons Attribution License, which permits unrestricted use, distribution, and reproduction in any medium, provided the original author and source are credited. 
Citation: Aleksic T, Worrall AR, Verrill C, Turley H, Campo L, et al. (2016) Improved Immunohistochemical Detection of Type 1 Insulin-Like Growth Factor Receptor in Human Tumors. Immunochem Immunopathol 2: 114. doi: 10.4172/2469-9756.1000114

Further complicating interpretation of IGF-1R IHC is the phenomenon of IGF-1R nuclear translocation, reported by several groups including ours [18-21]. In FFPE samples of human tumors, nuclear IGF-1R has been shown to associate with adverse prognosis in renal cancer [19], and with response to IGF-1R antibody in patients with sarcoma [21]. Lack of detection of nuclear IGF-1R prior to adoption of heat-based antigen retrieval $[5,19]$ suggests that this also is influenced by technical variation in IHC methods.

These findings highlight the insensitivity of some IHC protocols, and the difficulties inherent in assessing the biological and clinical significance of IGF-1R expression and subcellular localization. Likely sources of variation include use of different antigen retrieval protocols and IGF-1R antibodies, and lot-to-lot variation in polyclonal antibodies. These technical factors may confound attempts to understand the role of IGF-1R in tumor biology, and the assessment of IGF-1R as a candidate prognostic and predictive biomarker. The aim here was to develop a robust IGF-1R IHC staining protocol that can be used to address these questions.

\section{Materials and Methods}

We used formalin-fixed paraffin-embedded (FFPE) human tumors that were surplus to diagnostic need, available in the Department of Cellular Pathology, Oxford University Hospitals NHS Foundation
Trust, John Radcliffe Hospital, Oxford, and accessed under National Research Ethics approved study 07/H0606/120. As cell line controls, we used human MCF7 breast cancer, SKUT-1 leiomyosarcoma, PC3 prostate cancer, and A375M melanoma. IGF-1R depletion was induced by transfection with IGF-1R siRNA (Hs_IGF1R_1, Qiagen), with Allstars siRNA (Qiagen) as non-silencing control, as described [22]. Subconfluent cultures were scraped into ice-cold phosphate buffered saline (PBS), pelleted by centrifugation ( $1250 \mathrm{rpm}$ for 5 minutes, $4^{\circ} \mathrm{C}$ ) and resuspended in $10 \%$ neutral buffered formalin (NBF) for 1 hour at $23^{\circ} \mathrm{C}$ or overnight at $4^{\circ} \mathrm{C}$. After centrifugation (1250 rpm, $\left.5 \mathrm{~min}\right)$ the cell pellet was resuspended in $2 \% \mathrm{w} / \mathrm{v}$ formalin-agarose (Sigma A9414 agarose, melting temperature $87^{\circ} \mathrm{C}$, gelling temperature $36^{\circ} \mathrm{C}$, in NBF) equilibrated to $60-65^{\circ} \mathrm{C}$. After chilling on ice for $5-10 \mathrm{~min}$ the cell pellet was embedded in paraffin, from which $1 \mathrm{~mm}$ cores were removed and inserted into a recipient block using a tissue microarrayer (Beecher Instruments, Sun Prairie, WI, US), and annealed at $45-50^{\circ} \mathrm{C}$ for $20 \mathrm{~min}$. Parallel cultures were lysed for western blotting using IGF$1 \mathrm{R}$ antibodies and $\beta$-tubulin antibody (Sigma-Aldrich), as described [19]. IGF-1R IHC was performed on freshly-cut $4 \mu \mathrm{m}$ tissue and tissue microarray (TMA) sections using \#3027, \#9750 and \#14534 antibodies (Cell Signaling Technology). Table 1 shows the manual IHC protocol, which used methods based on Ref. [19,23], and Table 2 the automated protocol.

\begin{tabular}{|c|c|}
\hline Step & Protocol \\
\hline Dewax, rehydrate & $\begin{array}{l}\text { Incubate for } 8 \mathrm{~min} \text { in Citroclear (TCS Biosciences Ltd, UK), } 8 \text { min Citroclear, } 2 \text { min } 100 \% \text { ethanol, } 2 \text { min } 95 \% \text { ethanol, } 2 \text { min } \\
80 \% \text { ethanol, } 2 \text { min } 70 \% \text { ethanol, } 2 \text { min 50\% ethanol, } 10 \text { min distilled water }\left(\mathrm{dH}_{2} \mathrm{O}\right)\end{array}$ \\
\hline Antigen retrieval & $\begin{array}{l}\text { Buffer: } 50 \mathrm{mM} \text { Tris-Cl, } 2 \mathrm{mM} \text { EDTA pH } 9 \\
\text { Use Decloaking chamber (DC2002, Biocare Medical, USA or similar) at } 125^{\circ} \mathrm{C} \text { for } 2 \mathrm{~min}, 85^{\circ} \mathrm{C} \text { for } 10 \mathrm{~min} \text {. Cool to room } \\
\text { temperature }\left(\sim 23^{\circ} \mathrm{C}\right) \text { by placing slide chamber on ice for } 10-15 \mathrm{~min} \text {. }\end{array}$ \\
\hline Wash & Wash slides in PBS $3 \times 5$ min \\
\hline Block endogenous peroxidase & Incubate slides in $3 \% \mathrm{H}_{2} \mathrm{O}_{2}$ in $\mathrm{dH}_{2} \mathrm{O}$ at $23^{\circ} \mathrm{C}$ for $10 \mathrm{~min}$ \\
\hline Wash & Wash slides in PBS $3 \times 5 \mathrm{~min}$ \\
\hline Block & Incubate slides in $5 \%$ BSA $5 \%$ goat serum in PBS $1 \mathrm{hr}$ at $23^{\circ} \mathrm{C}$. Drain blocking solution with Kimwipe (do not wash away) \\
\hline Primary antibody & $\begin{array}{l}\text { Mark around tissue area with PAP pen. Place slides in humidified chamber, incubate with IGF-1R- } \beta \text { antibody } \# 9750 \text { (Cell } \\
\text { Signaling Technology), diluted } 1: 50 \text { in blocking solution ( } 5 \% \text { BSA } / 5 \% \text { goat serum in PBS), using } 200-500 \mu \text { lantibody } \\
\text { solution per slide depending on tissue area. Incubate on level surface at }+4^{\circ} \mathrm{C} \text { overnight. }\end{array}$ \\
\hline Wash & Wash slides in PBS $3 \times 5$ min \\
\hline Detection of bound antibody & $\begin{array}{l}\text { Use MP-531-M3R25, Menarini Diagnostics (Winnersh-Wokingham, Berkshire UK). Add } 1-3 \text { drops (depending on area to } \\
\text { cover) of rabbit probe (neat as supplied) for } 15 \mathrm{~min}\left(=5 \mathrm{~min} \text { to come to } \sim 23^{\circ} \mathrm{C} \text { plus recommended } 10 \mathrm{~min} \text { ). Wash in PBS } 3 \times\right. \\
5 \mathrm{~min} \text {, incubate with rabbit HRP polymer (neat as suplied) for } 15 \mathrm{~min} \text { at } 23^{\circ} \mathrm{C} \text {. }\end{array}$ \\
\hline Wash & Wash slides in PBS $3 \times 5$ min \\
\hline Color development & Incubate with DAB substrate (Envision) for 5-7 min \\
\hline Wash & Wash slides in tap water $3 \times 2 \mathrm{~min}$ \\
\hline Counterstain & Counterstain with Mayer's haematoxylin (Vector Laboratories, USA) for $40 \mathrm{sec}$ \\
\hline Wash & Wash slides in copious tap water until water runs clear \\
\hline Dehydrate & $\begin{array}{l}\text { Incubate slides for } 2 \mathrm{~min} \text { in } 50 \% \text { ethanol, } 2 \mathrm{~min} 70 \% \text { ethanol, } 2 \mathrm{~min} 80 \% \text { ethanol, } 2 \mathrm{~min} 95 \% \text { ethanol, } 2 \mathrm{~min} 100 \% \text { ethanol, } \\
5 \text { min in Citroclear }\end{array}$ \\
\hline Mount & Mount using DePex reagent (VWR International, UK) \\
\hline
\end{tabular}

Table 1: Protocol for preferred manual IGF-1R IHC. This is a modification of the protocol reported in Ref. [19,23] using IGF-1R antibody \#9750, and detecting bound antibody with reagents from MP-531-M3R25, Menarini Diagnostics (Winnersh-Wokingham, Berkshire UK).

\section{Results and Discussion}

In our initial study of IGF-1R expression in prostate cancer, we had used polyclonal antibody sc713 (Santa Cruz) [5]. In a later study [24], sc713 was insufficiently specific, and we re-optimized our IHC protocol to another polyclonal, \#3027 (Cell Signaling Technology) [19,24]. This antibody performed acceptably in western blotting (e.g., Ref. $[19,25]$, but we recently questioned the specificity of current lots of this antibody in IHC. Therefore, we tested currently available lots of \#3027 in IHC using FFPE sections of MCF7 and SKUT-1 cells, which express high and low IGF-1R respectively. Using the manual IHC protocol, there was detectable IGF-1R staining in both MCF7 and SKUT-1 cells, signal in the latter suggesting lack of specificity (Figure 1A). In comparison, monoclonal antibody \#9750 showed greater differentiation between SKUT-1 and MCF7 cells. We also compared \#3027 and \#9750 by western blotting of cancer cell lysates (Figure 1B). Probing of duplicate membranes confirmed that both antibodies detected immunoreactive IGF-1R of the predicted size: mature IGF-1R beta subunit of $98 \mathrm{kDa}$ and IGF-1R pro-receptor of $220 \mathrm{kDa}$. We noted that \#3027 generated stronger signal than \#9750, paralleling differences seen in IHC (Figure 1A). IGF-1R expression was relatively high in MCF7, lower but clearly 
Citation: Aleksic T, Worrall AR, Verrill C, Turley H, Campo L, et al. (2016) Improved Immunohistochemical Detection of Type 1 Insulin-Like Growth Factor Receptor in Human Tumors. Immunochem Immunopathol 2: 114. doi: 10.4172/2469-9756.1000114

Page 3 of 5

\begin{tabular}{|c|c|}
\hline Step & Protocol \\
\hline Bake, Dewax, rehydrate & $\begin{array}{l}\text { Leica Bondmax autostainer standard bake at } 60^{\circ} \mathrm{C} \text { for } 30 \mathrm{~min} \text {, followed by standard dewax and rehydrate program using } \\
\text { Leica Dewax solution (Cat no. AR9222), } 100 \% \text { ethanol and deionized water. }\end{array}$ \\
\hline Antigen retrieval & Leica ER2 buffer $\mathrm{pH} 920 \mathrm{~min} 100^{\circ} \mathrm{C}$ \\
\hline Wash & Bondmax standard wash protocol with Bond wash solution (Cat no. AR9590) \\
\hline Block endogenous peroxidase & Peroxidase block at $23^{\circ} \mathrm{C}$ for 5 min with Bond Polymer Refine kit (Cat no. DS9800) \\
\hline Wash & Bondmax standard wash protocol with Bond wash solution \\
\hline Primary antibody & Diluted 1:50 in Bond antibody diluent (Cat no. AR9352) for $1 \mathrm{hr}$ at $23^{\circ} \mathrm{C}$ \\
\hline Wash & Bondmax standard wash protocol with Bond wash solution \\
\hline Detection of bound antibody & $\begin{array}{l}\text { Post Primary Antibody }\left(8 \mathrm{~min} \text { at } 23^{\circ} \mathrm{C}\right) \text { followed by standard wash and polymer from Bond Polymer Refine kit (Cat no. } \\
\text { DS9800) for } 8 \text { min at } 23^{\circ} \mathrm{C}\end{array}$ \\
\hline Wash & Bondmax standard wash protocol with Bond wash solution \\
\hline Color development & DAB $10 \mathrm{~min}$ at $23^{\circ} \mathrm{C}$ from Bond Polymer Refine kit (Cat no. DS9800) \\
\hline Wash & Standard Bond wash with distilled water. \\
\hline Counterstain & Haematoxylin 5 min from Bond Polymer Refine kit (Cat no. DS9800) \\
\hline Wash & Standard Bond wash with distilled water. \\
\hline Mount & Aquatex aqueous mountant (Cat no 3631235 , VWR). \\
\hline
\end{tabular}

Table 2: Automated IGF-1R IHC protocol. This protocol was tested on a Leica Bondmax autostainer to evaluate antibodies \#9750 and \#14534. The method produced acceptable specificity and sensitivity in cell controls (Figure 1D) but generated very weak staining in FFPE tissue (see Figure 2A) and is not recommended for future studies.

detectable in A375M melanoma cells, and low/undetectable in SKUT1, PC3 and A375M cells in which IGF-1R was depleted by siRNA transfection (Figure 1B). These relative expression levels correspond to findings of our previous studies $[19,25,26]$. Comparable differences in signal were detected when we stained the control TMA with \#9750 (Figure 1C). The close parallels between the relative intensity of IGF$1 \mathrm{R}$ signal on western blot and IHC suggest that this antibody was sufficiently sensitive to detect differences in endogenous IGF-1R expression and changes induced by IGF-1R gene silencing. We then tested \#9750 in parallel with a more recently-available IGF-1R rabbit monoclonal, \#14534, comparing manual IHC with automated IHC on a Leica-Bond auto-stainer. Both antibodies showed clear discrimination between high IGF-1R MCF7 cells and IGF-1R-deficient SKUT-1 cells, with generally lower signal in the auto-stained samples (Figure 1D).

Having confirmed the specificity of both monoclonal antibodies in control cells of known IGF-1R expression, we performed testing in FFPE samples of human cancer. Staining of prostate cancer using manual and automated IHC showed negligible signal using either antibody at 1:200 dilution, and detectable signal at 1:50 that was more intense in the epithelial than stromal components, as previously noted [5]. The two antibodies showed different staining patterns, with faint membrane and more marked intracellular staining by \#9750, and pronounced membrane staining by \#14534. In both cases, the staining was much fainter in the auto-stained slides (Figure 2A). Finally, we analysed IGF-1R expression and subcellular localization in clear cell renal cancer, in which we had detected prominent nuclear IGF-1R in our previous study [19]. At low power it was apparent that \#9750 gave stronger staining than \#14534 (Figure 2B, left). As in prostate cancer (Figure 2A), \#14534 showed prominent membrane IGF-1R, while \#9750 showed membrane and cytoplasmic signal. In \#9750-stained tumor there was clear detection of nuclear IGF-1R that showed cell to cell variation, recapitulating appearances generated by previous lots of \#3027 in our prior study (Figure 2B, upper center and right panels; compare Figure $4 \mathrm{~B}$ panel $\mathrm{H}$ in Ref. [19]. In contrast nuclear IGF-1R was only faintly detected by \#14534 (Figure 2B lower). Given that nuclear IGF-1R is detectable by a range of methods including subcellular fractionation, immunofluorescence, proximity ligation assay and chromatin immunoprecipitation, and is reported to have prognostic and predictive significance [18-21], we suggest that \#9750 is preferable to \#14534 when using IHC to study IGF-1R expression and subcellular localization in human tumors.

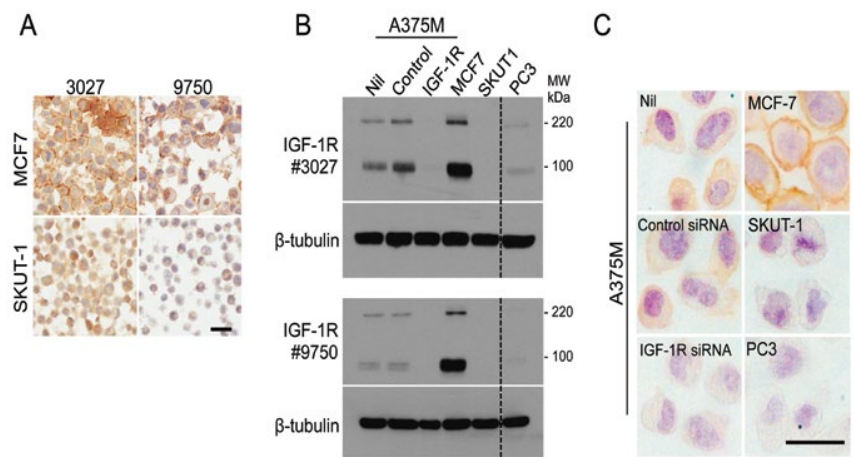

D

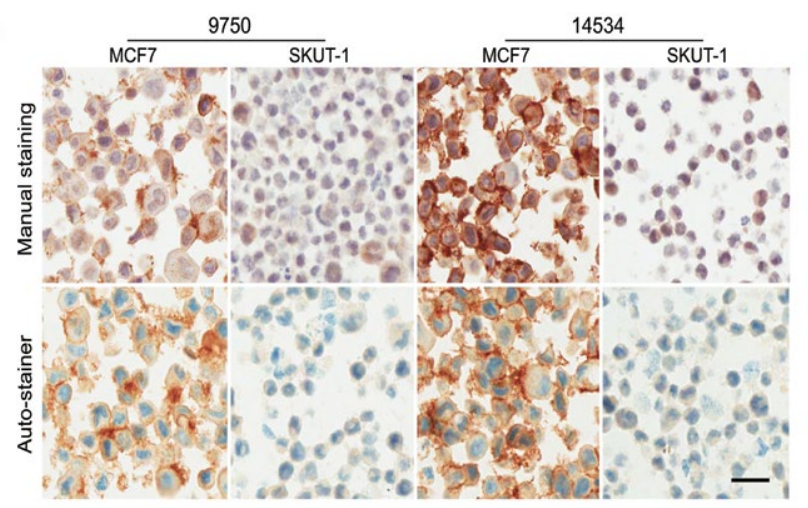

Figure 1: IGF-1R detection using polyclonal and monoclonal IGF-1R antibodies in human cancer cells. A. Manual IHC was performed on IGF-1R expressing MCF7 and IGF-1R deficient SKUT-1 cells using polyclonal antibody \#3027 at 1:200 or monoclonal $\# 9750$ at 1:50 dilution. Scale bar $20 \mu \mathrm{m}$. B. A375M cells were untransfected (Nil) or transfected with control or IGF-1R siRNA. Other cell lines were untransfected. Whole cell lysates $(50 \mu \mathrm{g})$ were analysed by western blot using 1:1000 dilution of \#3027 (upper) or \#9750 (lower), showing detection of IGF-1R $\beta$ (98 kDa) and IGF-1R pro-receptor (220 kDa). Membranes were reprobed for $\beta$-tubulin as loading control. Dotted line: one lane removed. C. Manual IHC on control TMA using $\# 9750$ antibody at 1:50, showing representative appearances of FFPE cell pellets made from parallel cultures to those used in B. Scale bar $20 \mu \mathrm{m}$. D. IGF-1R IHC on FFPE sections of MCF7 and SKUT-1 cells using \#9750 or \#14534 at 1:50 in manual (upper) or automated (lower) IHC. Scale bar $20 \mu \mathrm{m}$ 
Citation: Aleksic T, Worrall AR, Verrill C, Turley H, Campo L, et al. (2016) Improved Immunohistochemical Detection of Type 1 Insulin-Like Growth Factor Receptor in Human Tumors. Immunochem Immunopathol 2: 114. doi: 10.4172/2469-9756.1000114

A

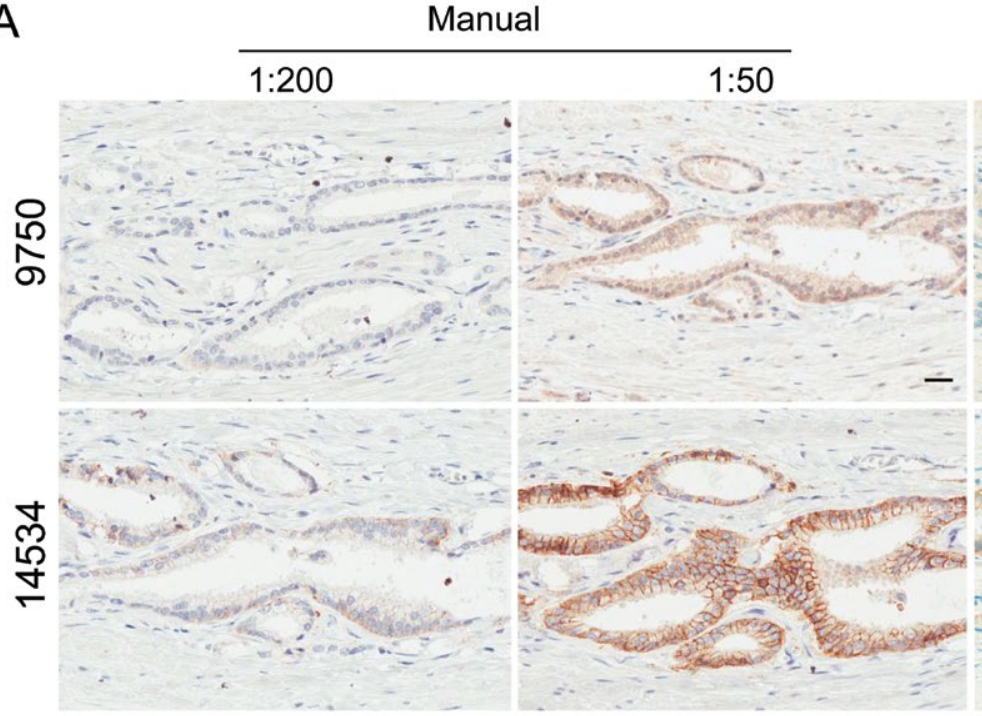

Auto-stainer

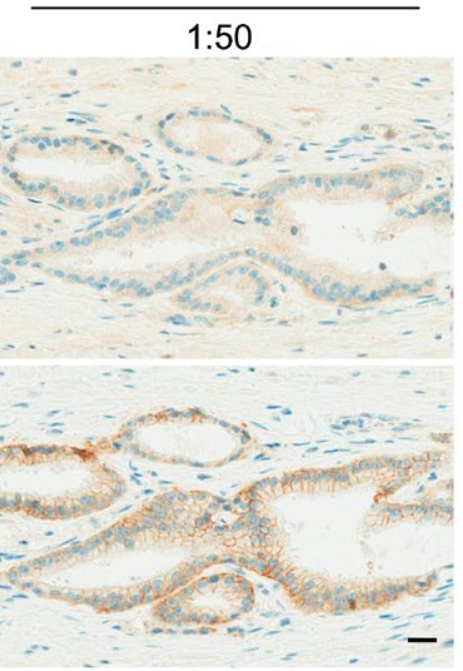

B

Original magnification $x 4$ $x 20$ $\mathrm{x} 40$

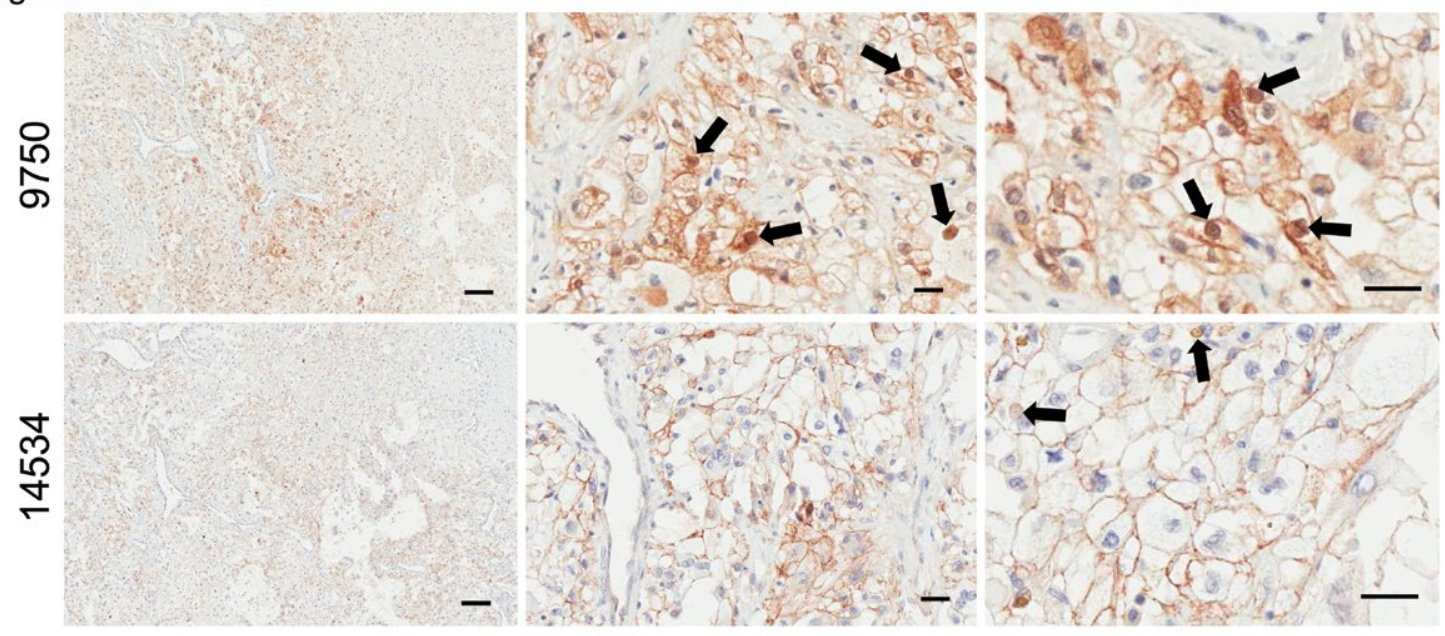

Figure 2: Comparison of manual and automated IGF-1R IHC using monoclonal IGF-1R antibodies in human tumors. A. Adjacent sections of prostate cancer stained using IGF-1R antibodies \#9750 or \#14534 at 1:200 or 1:50 in manual and automated protocols. Scale bar $20 \mu \mathrm{m}$. B. Clear cell renal cancer, fresh sections cut from same tumor block stained in Figure 4B panel H in (Aleksic et al. 2010), manually stained with \#9750 or \#14534 at 1:50. Scale bar for images taken at X4, $100 \mu \mathrm{m}$, and for X20-X40, $20 \mu \mathrm{m}$. Black arrows: nuclei positive for IGF-1R.

In conclusion, we developed a specific and sensitive manual IHC protocol using antibody \#9750. This is a monoclonal antibody, ensuring consistent antibody supply in future work. Nuclear IGF-1R was only weakly detected by antibody \#14534, and auto-staining did not recapitulate appearances of the manual \#9750 protocol, likely reflecting differences in antigen retrieval and detection. We provide a detailed protocol for the preferred manual IGF-1R IHC method that we commend for future studies. Adoption of a uniform protocol should reduce inter-study variation and may help to clarify whether responses to anti-IGF drugs associate with IGF-1R expression or subcellular localization.

\section{Acknowledgements}

This study was supported by funding to TA and VMM from Prostate Cancer UK National Institute for Health Research (NIHR) Research Capability Funding, NIHR Oxford Biomedical Research Centre and the Development Fund of the Oxford Cancer Research Centre. We are grateful to Adam Peltan, New England Biolabs UK for technical support.

\section{References}

1. Baserga R, Hongo A, Rubini M, Prisco M, Valentinis B (1997) The IGF-I receptor in cell growth, transformation and apoptosis. Biochim Biophys Acta 1332: F105-126 
Citation: Aleksic T, Worrall AR, Verrill C, Turley H, Campo L, et al. (2016) Improved Immunohistochemical Detection of Type 1 Insulin-Like Growth Factor Receptor in Human Tumors. Immunochem Immunopathol 2: 114. doi: 10.4172/2469-9756.1000114

Page 5 of 5

2. Chitnis MM, Yuen JS, Protheroe AS, Pollak M, Macaulay VM (2008) The type 1 insulin-like growth factor receptor pathway. Clin Cancer Res 14: 6364-6370.

3. Tennant MK, Thrasher JB, Twomey PA, Drivdahl RH, Birnbaum RS, et al (1996) Protein and messenger ribonucleic acid (mRNA) for the type 1 insulinlike growth factor (IGF) receptor is decreased and IGF-II mRNA is increased in human prostate carcinoma compared to benign prostate epithelium. J Endocrinol Metab 81: 3774-82.

4. Chott A, Sun Z, Morganstern D, Pan J, Li T, et al. (1999) Tyrosine kinases expressed in vivo by human prostate cancer bone marrow metastases and loss of the type 1 insulin-like growth factor receptor. Am J Pathol 155: 1271-1279.

5. Hellawell GO, Turner GD, Davies DR, Poulsom R, Brewster SF, et al. (2002) Expression of the type 1 insulin-like growth factor receptor is up-regulated in primary prostate cancer and commonly persists in metastatic disease. Cancer Res 62: 2942-2950.

6. Grzmil M, Hemmerlein B, Thelen P, Schweyer S, Burfeind P (2004) Blockade of the type I IGF receptor expression in human prostate cancer cells inhibits proliferation and invasion, up-regulates IGF binding protein-3, and suppresses MMP-2 expression. J Pathol 202: 50-59.

7. Liao Y, Abel U, Grobholz R, Hermani A, Trojan L, et al. (2005) Up-regulation of insulin-like growth factor axis components in human primary prostate cancer correlates with tumor grade. Hum Pathol 36: 1186-1196.

8. Ryan CJ, Haqq CM, Simko J, Nonaka DF, Chan JM, et al. (2007) Expression of insulin-like growth factor-1 receptor in local and metastatic prostate cancer. Urol Oncol 25: 134-140.

9. Tolcher AW, Sarantopoulos J, Patnaik A, Papadopoulos K, Lin CC, et al. (2009) Phase I, pharmacokinetic, and pharmacodynamic study of AMG 479, a fully human monoclonal antibody to insulin-like growth factor receptor 1 . J Clin Oncol 27: 5800-5807.

10. King H, Aleksic T, Haluska P, Macaulay VM (2014) Can we unlock the potentia of IGF-1R inhibition in cancer therapy? Cancer Treat Rev 40: 1096-1105.

11. Cao L, Yu Y, Darko I, Currier D, Mayeenuddin LH, et al. (2008) Addiction to elevated insulin-like growth factor I receptor and initial modulation of the AKT pathway define the responsiveness of rhabdomyosarcoma to the targeting antibody. Cancer Res 68: 8039-8048.

12. Zha J, O'Brien C, Savage H, Huw LY, Zhong F, et al. (2009) Molecular predictors of response to a humanized anti-insulin-like growth factor-I receptor monoclonal antibody in breast and colorectal cancer. Mol Cancer Ther 8: 2110-2121.

13. Gong Y, Yao E, Shen R, Goel A, Arcila M, et al. (2009) High expression levels of total IGF-1R and sensitivity of NSCLC cells in vitro to an anti-IGF-1R antibody (R1507). PLoS One 4: e7273.

14. Huang F, Greer A, Hurlburt W, Han X, Hafezi R, et al. (2009) The mechanisms of differential sensitivity to an insulin-like growth factor-1 receptor inhibito (BMS-536924) and rationale for combining with EGFR/HER2 inhibitors. Cancer Res 69: 161-170.
15. Browne BC, Eustace AJ, Kennedy S, O'Brien NA, Pedersen K et al. (2012) Evaluation of IGF1R and phosphorylated IGF1R as targets in HER2-positive breast cancer cell lines and tumours. Breast Cancer Res Treat 136: 717-727.

16. Wynes ME, Asuncion S, Dziadziuszko BR, Glisson R, Wisuba BS, et al. (2012) Insulin-like growth factor (IGF-1R) protein expression (PE) and gene copy number $(9 \mathrm{GCN})$ for discrimination of response and outcome to figitumumab in NSCLC. J Clin Oncol 30: 7597.

17. Schwartz GK, Tap WD, Qin LX, Livingston MB, Undevia SD, et al. (2013) Cixutumumab and temsirolimus for patients with bone and soft-tissue sarcoma: a multicentre, open-label, phase 2 trial. Lancet Oncol 14: 371-382.

18. Sehat B, Tofigh A, Lin Y, Trocmé E, Liljedahl U, et al. (2010) SUMOylation mediates the nuclear translocation and signaling of the IGF-1 receptor. Sci Signal 3: ra10.

19. Aleksic T, Chitnis MM, Perestenko OV, Gao S, Thomas PH, et al. (2010) Type 1 insulin-like growth factor receptor translocates to the nucleus of human tumor cells. Cancer Res 70: 6412-6419.

20. Sarfstein R, Pasmanik-Chor M, Yeheskel A, Edry L, Shomron N, et al. (2012) Insulin-like growth factor-I receptor (IGF-IR) translocates to nucleus and autoregulates IGF-IR gene expression in breast cancer cells. J Biol Chem 287 2766-2776.

21. Asmane I, Watkin E, Alberti L, Duc A, Marec-Berard P, et al. (2012) Insulin-like growth factor type 1 receptor (IGF-1R) exclusive nuclear staining: a predictive biomarker for IGF-1R monoclonal antibody $(\mathrm{Ab})$ therapy in sarcomas. Eur $\mathrm{J}$ Cancer 48: 3027-3035

22. Chitnis MM, Lodhia KA, Aleksic T, Gao S, Protheroe AS, et al. (2014) IGF-1R inhibition enhances radiosensitivity and delays double-strand break repair by both non-homologous end-joining and homologous recombination. Oncogene 33: $5262-5273$.

23. Dale OT, Aleksic T, Shah KA, Han C, Mehanna H, et al. (2015) IGF-1R expression is associated with HPV-negative status and adverse survival in head and neck squamous cell cancer. Carcinogenesis 36: 648-655.

24. Turney BW, Turner GD, Brewster SF, Macaulay VM (2011) Serial analysis of resected prostate cancer suggests up-regulation of type 1 IGF receptor with disease progression. BJU Int 107: 1488-1499.

25. Lodhia KA, Gao S, Aleksic T, Esashi F, Macaulay VM (2015) Suppression of homologous recombination sensitizes human tumor cells to IGF-1R inhibition. Int J Cancer 136: 2961-2966.

26. Ramcharan R, Aleksic T, Kamdoum WP, Gao S, Pfister SX, et al. (2015) IGF$1 \mathrm{R}$ inhibition induces schedule-dependent sensitization of human melanoma to temozolomide. Oncotarget 6: 39877-39890. 